\title{
Practice, preference and performance of cattle under peri-urban dairy management system in Mymensingh
}

\author{
NU Siddiquee ${ }^{1}$, SMA Rahman", MSA Bhuiyan", AKMA Rahman², MR Amin ${ }^{3}$, AKFH Bhuiyan* $^{1}$ \\ ${ }^{1}$ Department of Animal Breeding and Genetics; ${ }^{2}$ Department of Medicine, Bangladesh Agricultural University, \\ Mymensingh 2202, Bangladesh; ${ }^{3}$ Faculty of Agro Based Industry, University Malaysia Kelantan, Malaysia
}

\begin{abstract}
The objective of this research was to assess the status of cattle in respect of breeding system, quality of breeding services, their production, reproduction, health status, management system and marketing system using an in-depth baseline survey. The mean of homestead land owned by the farmers was $36.17 \pm 32.94$ decimal and most of them (48.3\%) own very low homestead land (11-50 decimal). Average cultivable land owned was found as 101.52 \pm 61.044 decimal and a considerable number of farmers have medium (51-150 decimal) to high (151 onward decimal) land area. From the collected data, it is clear that most of the households have cattle and chicken. But among cattle owners, about $77.62 \%$ have lower number (1-3). Most of the farmers $69.8 \%$ use locally available grass and only $3.2 \%$ fed exotic grass to their cows. Milk sale and consumption ( $52.13 \%$ ) was found as main objective behind cattle rearing. Semi-intensive method of rearing was found most acceptable $(77.62 \%)$ among the periurban farmers. Disease problem was quite high because of lack of routine vaccination where vaccination was found to be practiced by only $38.46 \%$ farmers. Indigenous cattle are of high preference among the farmers $(52.45 \%)$ because of its easy management and high resistance to disease, $41.2 \%$ percent farmers preferred crossbred cattle. Main reasons behind preference for Deshi cattle were easy management $(24.48 \%)$ and lower feed requirement $(12.59 \%)$ whereas, reason behind crossbred preference (35.66\%) was higher milk production. Artificial Insemination (AI) was preferred $(61.06 \%)$ over natural service (38.94\%). For artificial insemination, semen of Holstein Friesian $(43.07 \%)$ was preferred where Deshi was the second most choice (32.12\%). Most of the farmers ( $82.9 \%$ ) have no idea about genotype, quality \& merit of semen. Average milk yield of Deshi and crossbred genotype were found as $1.72 \pm 0.80$ and $6.65 \pm 5.05$ liter per day respectively whereas lactation period and dry period were found respectively as $243.98 \pm 113.13$ and $92.37 \pm 63.14$ days in crossbred, $249.69 \pm 106.93$ and $96.58 \pm 32.06$ days in Deshi cows.
\end{abstract}

Key words: Performance, peri-urban dairying, practice, preference

Bangladesh Animal Husbandry Association. All rights reserved.

Bang. J. Anim. Sci. 2013. 42 (2): 89-95

\section{I ntroduction}

Livestock plays an important role in the economy of Bangladesh with a direct contribution around $2.67 \%$ to the GDP and according to Bangladesh Economic Review (2010); the growth rate in GDP of 2011-2012 for livestock was at 3.39\%. The need of per capita milk and meat is $240 \mathrm{gm}$ and $120 \mathrm{~g} /$ day, respectively with a per capita availability of $43 \mathrm{ml} \mathrm{milk,} 21 \mathrm{~g}$ meat/ day (DLS 2005). So, it is clear that there is a huge shortage of livestock products in Bangladesh for human consumption.

Replication of successful pro-poor models for community based smallholder dairy development including contract farming schemes and

*Corresponding Author: bhuiyanbau@gmail.com development of national policy supported breeds/ genotypes have been suggested as vital elements of policy framework for dairy and breed development in Bangladesh (Anonymous 2007). The existing cattle breeding policy of the country is a two-tier system which kept provision of dairy development in the country using both i) high yielding variety which are crossbred e.g., Holstein Friesian $\times$ Local, and ii) improved indigenous dairy type cattle e.g., Red Chittagong, Pabna, Munshigonj, etc (Bhuiyan 2007). The gap between demand and supply of quality semen considered as one of the major constraints in enhancing productivity. To overcome the problem, it has become imperative to produce quality semen through active participation of the 
farmers. More importantly, farmers are the custodians of the most species of livestock and, therefore much better placed to manage these resources and to participate in semen animal production initiative in a science-led fashion (Bhuiyan 2007, Jabbar et al. 2010). Taking the aforementioned background in consideration the present study was undertaken to look at the farmers' preference of cattle breeds/genotypes and their performance under peri-urban dairy management systems in Mymensingh district of Bangladesh.

\section{Materials and Methods}

A field investigation was carried out in different parts of Mymensingh Sadar and some parts of Gauripur upazilla of Mymensingh district. In the field reconnaissance, the actual field situation was assessed by field visit of project personnels. Exchanges of opinions and views were carried out to identify the present status, problems and potentialities of rearing cattle. Farmers of Boyra, Ghagra, Vabokhali, Akua, Khagdohor, Dapunia, Char Ishwardia, Char Nilakshmia and Vangnamari union were selected for survey purposes.

Stratified random sampling procedure was applied for selecting the samples for conducting baseline survey from 203 households located in 61 villages in fewer than 9 unions (Table 1 ). From every village 2-3 households ( $\mathrm{HHs}$ ) with cattle and 1-2 HHs without cattle (Non-cattle) was surveyed. The baseline survey was conducted by direct interview method during the period from 24 J une to 07 J uly 2010.

For collecting the necessary data, the survey team explained to respondents about the aims and objectives of the baseline survey before going to make the actual interview. The respondents were assured that the information given by them would not be used against their interest and that it would be useful to the households themselves in many respects. Interviewees were requested to give correct information as far as possible. To ensure the quality of information the interview schedule was checked to ensure that information to each of the items had been correctly recorded. If there were any items overlooked and misunderstood or found contradictory, these were corrected through re-interviewing on the spot.
Table 1. Distribution of households where baseline survey was conducted

\begin{tabular}{lccc}
\hline Location & With Cattle & Without cattle & Total \\
\hline Barera & 23 & 9 & 32 \\
Ghagra & 15 & 5 & 20 \\
Bhabkhali & 17 & 8 & 25 \\
Akua & 19 & 9 & 28 \\
Char Ishwardia & 21 & 7 & 28 \\
Char & 10 & 5 & 15 \\
Nilakshmia & 16 & 6 & 22 \\
Khagdahar & 02 & 1 & 3 \\
Dapunia & 20 & 10 & 30 \\
Vangnamari & 143 & 60 & 203 \\
\hline Total & & &
\end{tabular}

The senior team members monitored the interviews as well as provided specific feedback to the enumerators regarding interview (e.g., questioning style, use of probing questions, and approach to the respondents). As a follow-up to cross check survey enumeration, senior team members re-interviewed some of the sample households for checking the process followed by the data enumerators. The senior team members also checked all completed questionnaires on a daily basis to identify the missing information, ambiguous answers, digital errors, and provided feedback to the enumerators (if any). All the collected data were uploaded in computer and compiled in single Excel file. These data were then rechecked referring filled questionnaire and analyzed in accordance with the objectives of the study. The analysis was done using descriptive statistics like percentage, frequency distribution and mean where appropriate.

\section{Results and Discussion}

Table 2 shows some basic information of the respondents in the survey area. The mean of homestead land owned by the farmers was $36.17 \pm 32.94$ decimal and most of them (48.3\%) own low category of homestead land (11-50 decimal). Mean value of cultivable land owned was found as 101.52 \pm 61.044 decimal and a considerable number of farmers have medium to high land area. Farming experience is very important for successful farming and average farming experience found was $25.36 \pm 23.75$ years. The mean family size was $6.26 \pm 2.42$, but most of the farmers $(70.9 \%)$ had a large size family (6-10). 
Table 3 describes information about number and different age groups of livestock reared by the farmers in the study area. From the collected data, it is clear that most of the households have cattle and chicken. But among cattle owners, about $77.62 \%$ have lower number (1-3). Most of the farmers are not interested in goat rearing. But chicken is common, average number owned is $4.42 \pm 3.71$ with an average of $5.29 \pm 5.10$ chicks.

The two different cattle genotypes were available in the project area which included crossbred (41.52\%) and Deshi (58.48\%). Each genotype was further categorized as milch cow, pregnant cow, breeding bull, male and female calf. Among the cattle owners, $31.59 \%$ had milking crossbreds with 28.83 and $16.26 \%$ of female and male calves, respectively. Whereas, among 143 respondents, $23.52 \%$ and $30.50 \%$ had Deshi milking cows and female calves, respectively. A considerable number $(9.15 \%)$ of Deshi bulls were also found. But crossbred-bulls are relatively less in number $(7.36 \%)$.

Response from the cattle owners is presented in Figure 1 . Among them, $52.13 \%$ are being reared for milk sale and consumption. The second important objective was selling of cattle as a business (31.19\%). Besides these, there are other purposes as- cultivation of land, religious purpose, festival etc.

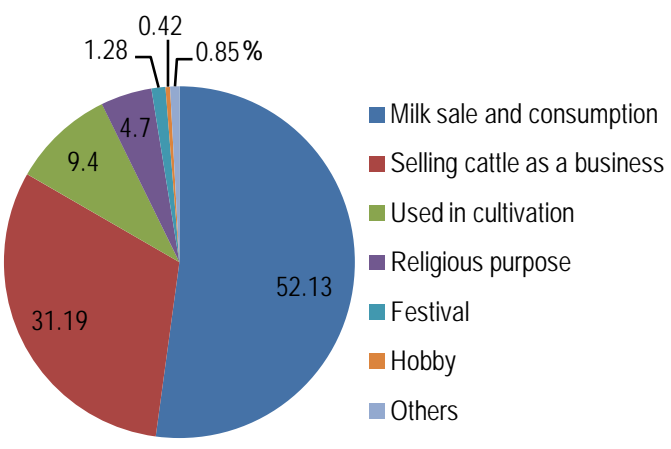

Figure 1. Objective of cattle rearing

Semi-intensive method of rearing was found mostly followed $(77.62 \%$ of cattle owners) by the farmers (Figure 2). In addition, rearing all types of cattle together $(71.33 \%)$ is preferred than that of separately $(6.29 \%)$. Rahman et al. (2013) found that about $80 \%, 17 \%$ and $3 \%$ farmers reared cattle by semi-intensive, intensive and extensive or free grazing system, respectively which is very similar of these results.

Table 2. Primary information of the farmers

\begin{tabular}{|c|c|c|c|c|}
\hline Primary information & Category & $\mathrm{HH}$ & $\%$ of total & Mean \pm SD \\
\hline \multirow{4}{*}{ Homestead land (decimal) } & Very low (0-10) & 52 & 26.40 & \multirow{4}{*}{$36.17 \pm 32.94$} \\
\hline & Low $(11-50)$ & 98 & 49.74 & \\
\hline & Medium (51-150) & 46 & 23.35 & \\
\hline & High (151-upward) & 1 & 0.5 & \\
\hline \multirow{4}{*}{ Cultivable land (decimal) } & Very low $(0-10)$ & 01 & 0.9 & \multirow{4}{*}{$101.52 \pm 61.044$} \\
\hline & Low $(11-50)$ & 29 & 27.62 & \\
\hline & Medium (51-150) & 53 & 50.48 & \\
\hline & High (151-upward) & 22 & 20.95 & \\
\hline \multirow{4}{*}{ Farming experience (year) } & No experience $(0)$ & 49 & 24.1 & \multirow{4}{*}{$25.36 \pm 23.75$} \\
\hline & Moderate (1-15) & 45 & 22.2 & \\
\hline & Medium (16-30) & 35 & 17.2 & \\
\hline & High (31-upward) & 74 & 36.5 & \\
\hline \multirow{4}{*}{ Family members } & Low $(0-2)$ & 5 & 2.5 & \multirow{4}{*}{$6.26 \pm 2.42$} \\
\hline & Medium (3-5) & 43 & 21.2 & \\
\hline & High $(6-10)$ & 144 & 70.9 & \\
\hline & Very high (11-upward) & 11 & 5.4 & \\
\hline
\end{tabular}

$\mathrm{HH}$, household; SD, standard deviation 
Peri- urban dairy management

Table 3. Information about the number of livestock in the households (203)

\begin{tabular}{|c|c|c|c|c|c|c|}
\hline \multirow{3}{*}{$\begin{array}{l}\text { Species and } \\
\text { Category }\end{array}$} & \multicolumn{6}{|c|}{ Different stages of livestock } \\
\hline & \multicolumn{2}{|c|}{ Adult } & \multicolumn{2}{|c|}{ Grower } & \multicolumn{2}{|c|}{ Calf/Kid/Chick/Duckling } \\
\hline & $\%$ & Mean \pm SD & $\%$ & Mean \pm SD & $\%$ & Mean \pm SD \\
\hline Cattle: & $8.72(13)$ & & $22(22)$ & & $10.85(14)$ & \\
\hline Low (1-4) & $85.23(127)$ & $2.21 \pm 1.68$ & $72(72)$ & $1.56 \pm 1.40$ & 82.95 (107) & $1.83 \pm 1.43$ \\
\hline Medium (5- 10) & $6.04(09)$ & & $1106(06)$ & & $6.20(08)$ & \\
\hline Goat: & $14.93(10)$ & & $19.05(4)$ & & $27.03(10)$ & \\
\hline Low $(1-4)$ & $80.6(54)$ & $1.69 \pm 1.62$ & $71.43(15)$ & $1.90 \pm 1.87$ & $67.57(25)$ & $1.59 \pm 1.46$ \\
\hline Medium $(5-10)$ & $4.48(3)$ & & $9.52(2)$ & & $9.52(2)$ & \\
\hline Chicken: & $12.03(19)$ & & $25.37(17)$ & & 35.78 (39) & \\
\hline Low $(1-5)$ & $64.56(102)$ & $4.42 \pm 3.71$ & $56.72(38)$ & $3.63 \pm 3.14$ & $18.35(20)$ & $5.29 \pm 5.10$ \\
\hline Medium (6-15) & $23.42(37)$ & & $17.91(12)$ & & $45.88(50)$ & \\
\hline Duck: & $15.46(13)$ & & $27.54(7)$ & & $27.59(08)$ & \\
\hline Low (1-5) & $58.89(53)$ & $4.26 \pm 3.70$ & $38.46(10)$ & $4.38 \pm 4.03$ & 34.48 ( 10$)$ & $4.93 \pm 4.64$ \\
\hline Medium (6-15) & $26.67(24)$ & & $34.62(9)$ & & $37.93(11)$ & \\
\hline
\end{tabular}

The feeds and amount of feeds offered to their cattle in study area are summarized in Table 4. Normal straw are preferred by the farmer to fed animals which is about $84.9 \%, 84.44 \%$ and $81.48 \%$ for cow, heifer and bull, respectively. Most of the farmers use Deshi/locally available grass $(96.8 \%$ for cow), whereas only $3.2 \%$ (for cow) fed exotic grass. Among concentrates, wheat bran $(29.6 \%$ for cow), oil cake $(25.23 \%$ for cow), rice polish ( $18.38 \%$ for cow) are highly preferred. On an average, every cow gets one $\mathrm{kg}$ mixed concentrate feed daily, whereas heifer \& bull gets $0.45 \mathrm{~kg} /$ day $/$ animal, $0.27 \mathrm{~kg} /$ day $/$ animal respectively. Rahman et al. (2013) found that more than $84 \%$ of the farmers managed feed from both sources (own and purchased) for their cattle even though $15 \%$ fully depended on purchasing feed from local market, but a little (1\%) of them from their own sources which is very similar of this study.

Level of consumption of milk among the cattle owners was not so good; mean found was only $1.18 \pm 0.88$ liters daily, whereas mean sale of milk by farmers was $8.86 \pm 24.62$ liters daily. Average milk price in the surveyed area was Tk. $35.32 \pm 8.98 /$ liter. Milk selling channel that is used by most of the farmers is through milkman. About $56.25 \%$ of the respondents sell milk by the help of milkman, whereas $28.75 \%$ sale in retail by own. But it should be clear that a farmer can use more than one channel at a time. Most of the respondents $(62.35 \%)$ are not happy with the price.

During survey in the area, farmer's response on different constraints was considered. The main problems found were lack of good semen, low pregnancy (conception) rate, lack of inseminators, and high price of breeding service and unavailability of Al service. Most of the time, farmers mentioned more than one problem at a time.

About $98.64 \%$ of the respondents reported that they breed their cows based on their observation of sign of heat of cows (Table 5). About 38.94\% of the farmers still use natural breeding by bull, of which $58.87 \%$ bulls were Deshi type. Rahman et al. (2013) found that most of the farmers (76\%) inseminated their cows artificially rather than naturally (19\%) and merely of $5 \%$ did both, which is not similar of this study. The main Al service providers were government, BRAC and BAU Al center. BAU Al center provides service to about $61.36 \%$ of the total breed able cows in the surveyed area. Most of the farmers $(82.9 \%)$ had no knowledge about good (merit and quality) semen. 
Siddiquee et al. (2013) Bang. J. Anim. Sci. 42 (2): 89- 95

Table 4. Type of feeds and amount offered to cattle

\begin{tabular}{|c|c|c|c|c|c|c|c|}
\hline \multirow{2}{*}{$\begin{array}{l}\text { Feed types } \\
\text { and amount }\end{array}$} & \multirow{2}{*}{ Category } & \multicolumn{2}{|c|}{ Cow } & \multicolumn{2}{|c|}{ Heifer } & \multicolumn{2}{|c|}{ Bull } \\
\hline & & Frequency & $\%$ & Frequency & $\%$ & Frequency & $\%$ \\
\hline \multirow{2}{*}{ Straw } & Normal & 113 & 84.9 & 76 & 84.44 & 44 & 81.48 \\
\hline & Treated & 20 & 15.1 & 14 & 15.56 & 10 & 18.52 \\
\hline \multirow{2}{*}{ Grass } & Deshi & 121 & 96.8 & 78 & 95.12 & 49 & 94.23 \\
\hline & exotic & 4 & 3.2 & 4 & 4.88 & 3 & 5.77 \\
\hline \multirow{2}{*}{$\begin{array}{l}\text { Concentrate } \\
\text { Feeding }\end{array}$} & Yes & 73 & 51.05 & 39 & 27.27 & 32 & 22.38 \\
\hline & No & 70 & 48.95 & 104 & 72.73 & 111 & 77.62 \\
\hline \multirow{7}{*}{$\begin{array}{l}\text { Concentrated } \\
\text { feed } \\
\text { ingredients }\end{array}$} & Wheat bran & 95 & 29.60 & 55 & 27.64 & 44 & 30.78 \\
\hline & Oil cake & 81 & 25.23 & 49 & 24.62 & 35 & 24.48 \\
\hline & Rice polish & 59 & 18.38 & 43 & 21.61 & 29 & 20.28 \\
\hline & Khude & 52 & 16.20 & 30 & 15.10 & 25 & 17.48 \\
\hline & Salt & 30 & 9.35 & 17 & 8.54 & 7 & 4.90 \\
\hline & Others & 4 & 1.25 & 5 & 2.51 & 3 & 2.09 \\
\hline & Fed/animal/day $(\mathrm{kg})$ & \multicolumn{2}{|c|}{1.03} & \multicolumn{2}{|c|}{0.45} & \multicolumn{2}{|c|}{0.27} \\
\hline
\end{tabular}

Disease management is one of the important pre-requisite of successful cattle rearing. Still a large number of farmers $(59.44 \%)$ are not attached to vaccination program. Vaccination for BQ, Anthrax and FMD are common (Table 6). About $41.96 \%$ of farmers reported death of cattle in last five years. Major causes of death were FMD and Anthrax. Farmers call registered veterinarian and quack almost in same proportion of 45.45 and $44.06 \%$. Mean of deworming per year was found $1.92 \pm 1.41$.

Farmer's preference towards genotype and reasons behind this preference is very much important for taking decision. More than fifty percent farmers $(52.45 \%)$ prefer Deshi while $41.26 \%$ prefer crossbred (Table 7 ). Main reasons behind preference for Deshi were easy management $(24.48 \%)$ and lower feed requirement (12.59\%), whereas important reason behind crossbred preference (35.66\%) was their higher milk production. Rahman et al. (2013) found that the cow genotypes, more than half $(61.16 \%)$ was of the indigenous which was significantly $(p<0.01)$ higher than the crossbreds $(38.84 \%)$ which is very similar of this study.

The lactation period of crossbred and Deshi cattle was 257.5 and 249.69 days, respectively (Table $8)$. The dry period was found higher in Deshi cattle (96.58 days) as compared to crossbred (92.37 days). Mean dry period found in all cattle types is within normal range ( $<120$ days). Generally, Deshi cows are milked once in a day, whereas crossbreds are milked more than single time. The average milk yield and lactation length of Deshi cows were 2.33 \pm 0.96 liters/d and 249.69 \pm 106.93 days, respectively. Conversely, the average milk yield and lactation length of crossbred cows were $9.72 \pm 6.50$ liters/d and $243.98 \pm 113.13$ days, respectively.

Table 5. Breeding information

\begin{tabular}{|c|c|c|c|}
\hline $\begin{array}{l}\text { Breeding } \\
\text { information }\end{array}$ & Category & $\begin{array}{l}\text { No of } \\
\text { Animal }\end{array}$ & $\%$ \\
\hline \multirow{2}{*}{ Sign of heat } & Shown & 218 & 98.64 \\
\hline & Silent & 3 & 1.36 \\
\hline \multirow{2}{*}{$\begin{array}{l}\text { Type of } \\
\text { service }\end{array}$} & Natural service & 88 & 38.94 \\
\hline & $\mathrm{Al}$ & 138 & 61.06 \\
\hline \multirow{4}{*}{$\begin{array}{l}\text { Sources of } \\
\text { Semen for } \mathrm{Al}\end{array}$} & Semen from & 22 & 25.0 \\
\hline & Government & & \\
\hline & Semen from BRAC & 12 & 13.63 \\
\hline & $\begin{array}{l}\text { Semen from BAUAI } \\
\text { Centre }\end{array}$ & 54 & 61.36 \\
\hline \multirow{2}{*}{$\begin{array}{l}\text { How farmer } \\
\text { get Al services }\end{array}$} & Cows at Al center & 30 & 60.0 \\
\hline & $\begin{array}{l}\text { Inseminator at } \\
\text { home }\end{array}$ & 20 & 40.0 \\
\hline \multirow{2}{*}{$\begin{array}{l}\text { Bull used in } \\
\text { natural service }\end{array}$} & Deshi & 73 & 58.87 \\
\hline & Cross breed & 51 & 41.13 \\
\hline \multirow{4}{*}{$\begin{array}{l}\text { Genotypes } \\
\text { used in Al }\end{array}$} & Friesian crossbred & 59 & 43.07 \\
\hline & Sahiwal & 20 & 14.60 \\
\hline & $\begin{array}{l}\text { Deshi (Red } \\
\text { Chittagong Cattle) }\end{array}$ & 54 & 39.41 \\
\hline & Others & 4 & 2.92 \\
\hline \multirow{2}{*}{$\begin{array}{l}\text { Knowledge } \\
\text { about semen }\end{array}$} & Yes & 33 & 17.10 \\
\hline & No & 160 & 82.90 \\
\hline
\end{tabular}




\section{Peri- urban dairy management}

Rahman et al. (2013) found that the average milk yield and lactation length of indigenous cows were $2.37 \pm 0.26 \mathrm{~kg} / \mathrm{d}$ and $276.56 \pm 19.17$ days, respectively. Conversely, the average milk was $9.33 \pm 2.44,3.00 \pm 0.38,3.16 \pm 0$ and $2.25 \pm 0.25 \mathrm{~kg} / \mathrm{d}$ for Holstein $\mathrm{x}$ Local, Sahiwal $\mathrm{x}$ Local, Sindhi $x$ Local and Chittagong $x$ Local cows, respectively. The average lactation length was $326.39 \pm 19.34,306.28 \pm 25.52,267.56 \pm 26.51$ and 260.18 \pm 14.52 days for Holstein $x$ Local, Sahiwal $x$ Local, Sindhi $x$ Local and Chittagong $x$ Local cows, respectively.

Table 6. Status of disease management

\begin{tabular}{|c|c|c|c|}
\hline Case & Category & Frequency & $\%$ \\
\hline \multirow{2}{*}{ Vaccination } & Yes & 55 & 38.46 \\
\hline & No & 85 & 59.44 \\
\hline \multirow{4}{*}{$\begin{array}{l}\text { Types of } \\
\text { vaccination done }\end{array}$} & Black Quarter & 23 & 29.11 \\
\hline & Anthrax & 26 & 32.91 \\
\hline & FMD & 29 & 36.71 \\
\hline & Septic Throat & 1 & 1.27 \\
\hline \multirow{2}{*}{$\begin{array}{l}\text { Cattle death in last } \\
5 \text { years }\end{array}$} & Yes & 60 & 41.96 \\
\hline & $\overline{\text { No }}$ & 77 & 53.85 \\
\hline \multirow{6}{*}{ Causes of death } & Black Quarter & 3 & 5.88 \\
\hline & Anthrax & 11 & 21.57 \\
\hline & $\overline{F M D}$ & 15 & 29.41 \\
\hline & Septic Throat & 2 & 3.92 \\
\hline & Bloat & 7 & 13.72 \\
\hline & Others & 13 & 25.50 \\
\hline \multirow{4}{*}{ Veterinary services } & $\begin{array}{l}\text { Registered } \\
\text { veterinary } \\
\text { doctor }\end{array}$ & 65 & 45.45 \\
\hline & Village Quack & 63 & 44.06 \\
\hline & Drug seller & 4 & 2.80 \\
\hline & Others & 2 & 1.39 \\
\hline $\begin{array}{l}\text { De-worming of } \\
\text { cattle (No./yr/herd) }\end{array}$ & \multicolumn{3}{|c|}{$1.92 \pm 1.41($ Mean \pm SD $)$} \\
\hline
\end{tabular}

The findings of the present study revealed the existing cattle rearing practices under peri-urban system of management which are more or less in line with similar production environments. The breed/genotype preference has found to be in accordance to their management level. That is Deshi is the choice of low input farmers and crossbreds are the choice of high input farmers. The reasons behind preference for Deshi were easy management and lower feed requirement, whereas important reason behind crossbred preference was their higher milk production. These findings corroborate with that of Rahman et al. (2013) where more than half (61.16\%) like indigenous which was significantly $(p<0.01)$ higher than the crossbreds (38.84\%). However, in the present study $43.07 \%$ farmers used $\mathrm{HF}$ crossbred semen while the degree of choice of Sahiwal and Red Chittagong semen by the farmers were 14.60 and $39.41 \%$ respectively.

Table 7. Cattle preference of the farmers and reasons behind

\begin{tabular}{|c|c|c|c|c|c|}
\hline \multirow{2}{*}{\multicolumn{2}{|c|}{ Category }} & \multicolumn{2}{|c|}{ Crossbred } & \multicolumn{2}{|c|}{ Deshi } \\
\hline & & $\mathrm{HH}$ & $\%$ & $\mathrm{HH}$ & $\%$ \\
\hline \multicolumn{2}{|c|}{ Overall Cattle preferences } & 59 & 41.26 & 75 & 52.45 \\
\hline \multirow{13}{*}{ 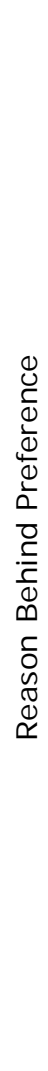 } & $\begin{array}{l}\text { High milk } \\
\text { production }\end{array}$ & 51 & 35.66 & 5 & 3.50 \\
\hline & $\begin{array}{l}\text { High milk price } \\
\text { and profitable }\end{array}$ & 12 & 8.39 & 4 & 2.80 \\
\hline & $\begin{array}{l}\text { Milk quality high } \\
\text { or tasty }\end{array}$ & 1 & 0.70 & 7 & 4.90 \\
\hline & $\begin{array}{l}\text { High growth } \\
\text { rate and tasty } \\
\text { meat }\end{array}$ & 5 & 3.50 & 4 & 2.80 \\
\hline & Regular calving & 1 & 0.70 & 6 & 4.20 \\
\hline & $\begin{array}{l}\text { Easy } \\
\text { management or } \\
\text { rearing }\end{array}$ & 3 & 2.10 & 35 & 24.48 \\
\hline & $\begin{array}{l}\text { Low rearing } \\
\text { cost }\end{array}$ & 0 & 0 & 9 & 6.29 \\
\hline & $\begin{array}{l}\text { Low feed } \\
\text { needed }\end{array}$ & 1 & 0.70 & 18 & 12.59 \\
\hline & $\begin{array}{l}\text { Less disease } \\
\text { risk }\end{array}$ & 1 & 0.70 & 9 & 6.29 \\
\hline & $\begin{array}{l}\text { Low space } \\
\text { needed }\end{array}$ & 0 & 0 & 3 & 2.10 \\
\hline & Ploughing & 1 & 0.70 & 7 & 4.90 \\
\hline & Nice looking & 2 & 1.40 & 3 & 2.10 \\
\hline & Best among all & 0 & 0 & 6 & 4.20 \\
\hline
\end{tabular}


Siddiquee et al. (2013) Bang. J. Anim. Sci. 42 (2): 89- 95

Table 8. Performance of different cattle genotypes

\begin{tabular}{lcccccc}
\hline & \multicolumn{5}{c}{ Mean } \\
\cline { 2 - 7 } Cattle Type & $\begin{array}{c}\text { Daily Milk } \\
\text { Yield (litre) }\end{array}$ & $\begin{array}{c}\text { Lactation Period } \\
\text { (day) }\end{array}$ & $\begin{array}{c}\text { Dry Period } \\
\text { (day) }\end{array}$ & Parity & $\begin{array}{c}\text { Number of } \\
\text { Milking/day }\end{array}$ & $\begin{array}{c}\text { Highest Milk } \\
\text { Production } \\
\text { (litre) }\end{array}$ \\
\hline Crossbred & $\begin{array}{c}6.65 \pm 5.05 \\
\text { ( }\end{array}$ & $243.98 \pm 113.13$ & $92.37 \pm 63.14$ & $2.63 \pm 1.44$ & $1.56 \pm 0.49$ & $9.72 \pm 6.50$ \\
Deshi & $1.72 \pm 0.80$ & $249.69 \pm 106.93$ & $96.58 \pm 32.06$ & $2.85 \pm 1.66$ & $1.03 \pm 0.16$ & $2.33 \pm 0.96$ \\
& $(103)$ & $(101)$ & $(76)$ & $(105)$ & $(108)$ & $(105)$ \\
\hline
\end{tabular}

* Case numbers are given in parentheses

\section{Conclusion}

Important information to note from this study is that $82.90 \%$ farmers had no knowledge about good semen or semen meaning that farmers used semen for breeding through Al without any information about the merit of semen. In general, it could be due to poor awareness among the farmers in this regard. These results therefore in Bangladesh suggested to stop current chaotic Al delivery and a combination of different strategies for breed improvement should be adopted and breeding research, development and service delivery need to be designed taking cognizance of perspectives of experts and farmers. The study infers that cattle breeding service providers should always make meritorious and quality semen available as per farmers' breed / genotype choice to optimize profitable dairy farming.

\section{References}

Anonymous (2007). National Livestock Development Policy. Government of the People's Republic of Bangladesh. Ministry of Fisheries and Livestock, P. 31.
Bangladesh Economic Review (2010). Finance division, Government of the People's Republic of Bangladesh, P. 83-93.

Bhuiyan AKFH (2007). Production of genetically potential breeding bulls for cattle development in Bangladesh. Keynote paper presented at the National Workshop- 2007 on Breed Upgradation through Progeny Test Project, Government of Bangladesh, BIAM Conference Hall, Dhaka, 16 June, P. 1-10.

DLS (2005). Development and Activities, Department of Livestock Services, Govt. of the People's Republic of Bangladesh.

Jabbar MA, Husain SS, Islam SMF, Amin MM, Khandaker MAMY, Bhuiyan AKFH, Ali SZ, Faruque O (2010). Stakeholder perspectives on breeding strategy and choice of breeds for livestock development in Bangladesh. Bangladesh Journal of Animal Science, 39: 20-43.

Rahman MM, Hoque MA, Saha NG, Faruque MO (2013). Studies on management system and identification of the causes of genetic erosion of indigenous cattle in Mymensingh district. Bangladesh Journal of Animal Science, 42: 23-28. 